\title{
Influence of Employer Brand Image on Employee Identity
}

\section{Fahim Shaker $^{1}$, A.S. Nooruddin Ahmed ${ }^{2}$}

${ }^{1}$ Lecturer, School of Business Studies, Southeast University, Dhaka, BANGLADESH

${ }^{2}$ Senior Lecturer, School of Business Studies, Southeast University, Dhaka, BANGLADESH

\begin{abstract}
This study aims to provide a framework of understanding the relation between employee identity construction and organization's employer brand image. Theoretically, employer brand image and identity construction are two different topics in different disciplines and have evolved separately from each others. The current paper tries to draw a relation between these two topics by addressing research work from employer branding, employee identity construction, literature on the dirty work and so forth. Drawing this relation is significantly important as in the future it may serve the framework of understanding about certain employee's positive or negative identity construction influenced by organization's positive or negative employer brand image. The arguments provided here are typically based on various scholars' findings relying on classic and contemporary text within organization theory, sociology and marketing. The paper suggests few empirical investigations as future scope of research to provide a concrete understanding of the relation between employee identity negotiation and organization's employer brand image.
\end{abstract}

Keywords: Employer branding, Identity work, Employer brand image, Identity construction JEL Classification Code: M 10; M 12; M 14

\section{INTRODUCTION}

Becoming an 'employer of choice' is a concept that had gained significant importance amongst employers in recent years. Moroko and Uncles (2009) described 'employer of choice' as significantly important concern amongst firms across U.S, Europe and Japan. Studies had contributed primarily towards the benefits of being an 'employer of choice'. For example, EOC helps to retain favorable customer image, increased workforce retention rates ( Sullivan, 1998, cited in Lenaghan and Eisner, 2005), helps to increase financial performance ( Becker and Huselid, 1999) and higher returns of the shareholders (Shellenbarger, 1998). More precisely, marketing and human resource management scholars (Ambler and Barrow, 1996; Moroko and Uncles, 2008) had tried to explore the underlying factors behind the development of an 'employer of choice'. Their findings suggested that individuals mostly 
associate their preference of employer with factors like 'employer attractiveness, the balance between individual-organization and the level of identification within the organization. Such findings had introduced concepts like 'employer branding' defined as "the package of functional, economic and psychological benefits provided by employment, and identified with the employing company" (Ambler and Barrow, 1996: 187). However, these studies primarily described the external approach of 'employer attractiveness' and rather tend to delimit their findings on how employees in such organizational setting make sense of their employers or identify with them. Therefore, the process of developing a firm into an 'employer of choice' from a theoretical perspective suggests that, individuals would prefer to be employed with organizations that were prestigious.

In other words, literature within 'employer branding' was favored more towards the development of a positive framework of an organization, which existing employees would comply with and associate themselves. Furthermore, it could be argued that employer branding shapes employee's identity to transform into a fixed set of values, stable (Alvesson et al. 2008) and expected to be consistent with the reframed positive image of the organization. On the other hand, recent studies within 'identity' and 'identity work' suggest that 'employees identity' is more towards an 'individualized approach', self defining and may remain independent of 'managerial identity regulation' (Alvesson and Wilmott, 2002). Precisely, employer branding could be argued as the new process of identity regulation through the mode of managerial control. Alvesson and Wilmott (2002: 625) described 'identity regulation' as "the more or less intentional effects of social practices upon processes of identity construction and reconstruction". Employer branding is described as "the process explicitly designed to shape employees' expectations by establishing and nurturing an emotional connection to the firm". (Crain, 2009: 1205). Martin and Hetrick (2006) argued that 'employer brand image' is being driven by the 'organizational identity' explained as collective answer of 'who we are' by managers, employees and a combined phenomenon of individual identities independent of the 'organizational identity. Therefore, organizational identity comprising of 'who we are' may have little to impact on individual identity comprising 'who am I' question. Since 'employer branding' is more about projecting a favorable image of the organization to others, it may be conflicting to include the cynical point of view of some of the organizational members if exist any. As a result, no recent empirical studies had explored to what extent 'employer branding' had been successful in organizational context. Much of these literatures were unable to explain why many people prefer to work for non-prestigious companies and like to retain their jobs.

\section{BACKGROUND RESEARCH ON EMPLOYER BRAND \& IDENTITY}

There had been studies in recent years demonstrate insights on why certain employers are preferred based on to what extent they could contribute towards employee's professional desire. These studies described identity as a mechanism towards a social construction. Some of these studies are- employee's engagement with the development of self-image and work orientation to make a meaning of their work (Alvesson and Wilmott, 2002); individual's effort to portray a positive and distinctive identity independent of totalized managerial discourses (Kuhn, 2006); individual's ability to maintain discursive tensions without eliminating these and thus contributing towards an empowered occupational identity (Meisenbach, 2008). Such studies had a common framework of analysis, individual's engagement towards identity negotiation.

Nevertheless, these studies portrayed the framework of 'identity negotiation' empirically, but concerns such as how identity is being negotiated in the context of organizational 
image were not explored through these studies. Hatch and Schultz (2002) argued that, the image of the organization is quite significant to influence organizational identity. Unfortunately, the research within organization studies didn't explore quite the relationship between organizational image and identity work. While it makes sense that, few of the research within organizational communication described organizational association as self-significant (Kuhn, 2002). Therefore, the current objective of the paper is to provide a conceptual framework on employer brand's influence over employee's interest in identity construction and how they identify with their employer.

Assuming 'employer branding 'concept to be heavily borrowed from the marketing literature the studies within the concept were mostly remained within marketing literature for instance its importance to prospective employers. For instance, Collins and Stevens (2002) stressed out the importance of external marketing for employer branding while Cable and Turban (2003) discussed about the strong employer brand's positive impact on individual's organizational membership. However, none of these studies or other empirical research within 'employer branding' did suggest its influence over employee identity construction. On the other hand, employer branding is described as the process of portraying an image of the firm to its prospective employees in the labor market as ' a great place to work'. The firm's image may not be taken into account as a singular image as it's a plural form of individual identities inconsistent with the firm's own identity (Martin and Hetrick, 2006). As a result, it can be theoretically assumed that within the 'employer branding' literature, a new insight is required which would explain employer brand's influence over employee identity construction. The new insights can explain whether 'employer brand image' (both positive and negative) have significant influence over employee's preference to retain/leave particular organizations.

\section{Objective of This Paper}

The current paper, therefore, is aimed towards addressing the gap within the existing literature by providing a literature review to explore employer brand's influence over employee identity construction. The paper doesn't empirically investigate the relation between employer brand images with employee's identity construction. However, the paper aims to provide a deeper insight into the literature of employer brand and identity construction which may facilitate future research in this paradigm. The research question that the authors aim to explore theoretically is "How employer brand image influence over employee's identity construction?" For the purpose of the study, a theoretical framework is required to develop which is discussed in the following section.

\section{Methodology}

Since the current paper is aimed towards theoretical explanation of employer brand's influence over identity construction, the authors preferred to follow an exploratory method of research. A numerous collection of research articles within the field of sociology, organization science and distinct marketing literature on employer branding are reviewed to conduct this study. Appropriate references are given in the bibliography section of the paper.

\section{Rationale of the Study}

The study may be proven beneficial to theoretically grasp the advanced literature on identity work and employee's negotiated identities in the presence of an employer brand image. Historically, identity negotiation in the context of the organization's employer brand image is not given much particular scholarly attention. This study may be helpful 
for us to understand how employees in an organization prefer to construct a positive identity despite existence of a negative employer brand image. Simultaneously, it may also help us to understand the rationale behind the presence of a negative identity despite the presence of a positive employer brand image. The study is strictly limited towards the theoretical justification to explain the employer brand's influence over identity negotiation. Therefore, future empirical studies are suggested to explain this issue further.

\section{LITERATURE REVIEW}

\section{EMPLOYEE IDENTITY CONSTRUCTION}

The concept of how employees in an organization construct their identities is an interesting topic of discussion amongst organizational communication scholars. According to Giddens (1991), the increasing complexities and the level of instability in terms of social security in a globalized world require employees to construct an emotional connection with the organization. Therefore, the concept of 'identity work' can be useful to explain how individuals in an organization construct their emotional connections with the organization. Sveningsson and Alvesson (2003) described employee identity construction as a central point of understanding employee motivation, commitment and their decision making within the organization. Precisely, 'identity work' is the core concept of 'employee identity construction' confining individual's requirements to remain positive and to make a balance in their lives. Individuals craft these adjustments through the process of selection, interpretation and recollection of self-confirming information while complying with numerous conflicts in organizational discourses (Alvesson and Wilmott, 2002). Basically, it may not be necessary to manage the organizational member's identity directly. The process of organizational control can be influenced by "managing the insides - the hopes, fears and aspirations" (Deetz, 1995: 87). Supporting that, Alvesson and Wilmott (2002) model can be helpful to explain the process of 'identity regulation' in the organization. Alvesson and Wilmott (2002: 622) described the 'new managerial discourses' as its role is to integrate with the management of self-identity by organizational members. Therefore, the process can be defined as identity work where the organizational members explained as 'identity workers' rejecting the role of management and organization in construction of employee identity. According to Alvesson and Wilmott, "Organizational members are not reducible to passive consumers of managerially designed and designated identities." (Alvesson and Wilmott, 2002: 621). Therefore, individuals in an organization indulge themselves into 'identity work' through their actions of formation, repair, sustain, reinforce or adjust their positive sense of self (Sveningsson and Alvesson, 2003, Alvesson and Wilmott, 2002). The concept of 'identity work' thus becomes helpful in bridging the gap between individuals, group or organizational levels. Additionally, it provides scope for researchers to look into the relationship amongst different targets of identification (Kärreman and Alvesson, 2001).

Despite the negative or external insecurities, employees attempt to build a more consistent level of identity defined as pre-carious self- identity (Alvesson and Wilmott, 2002). As a matter of fact, employees can be reluctant or hesitant to inter-relate their identity construction with the negative or external securities and rather prefer to construct a more positive self identity independent of external inconsistencies. We would like to explain this as a starting point to discuss why employees in an organization prefer to be loyal within the organization, retain their employment despite inconsistencies in the external insecurities. The external insecurity can be in the form of 'negative reputation' (Alvesson and Wilmott, 2002). 


\section{SOCIAL IDENTIFICATION- GROUP LEVEL IDENTITY}

Individuals may identify themselves with certain groups as members and thus define their 'social identity' (Asforth and Mael, 1989). It is "a perception of belongingness to a group and a sense of oneness with the group" (Asforth and Mael, 1989:198). Social identity is helpful in providing guidelines to individuals about their expected behavior to comply with group standard and norms (Alvesson, 2000). Most of the organizational studies had described 'organization' as a prominent source of identification of the individual, conforming domination of organizational identity towards 'identity work' of employees (Alvesson and Wilmott, 2002). On the other hand, an organization may not be defined as the primary foundation for individual's identification since the identity within the peer group professionals are also important in constructing individual's identity in a workforce (Scott, Corman and Cheney, 1998). The role of work team may play an important part building 'individual identity' according to the research of 'social identity', where there's a constant shift amongst individuals to different social identities. This shift of social identities is influenced by different social situations and how individuals perceive other's expectations in social group. Supported by earlier studies, we argue that individuals examine their actions, cognitive values from the perspective of others (Mead, 1934; Goffman, 1990). Mead (1934) argued that individuals responds to other's attitude in two ways, one can be described as "significant others" described the attitude of social circles and professional peers. This 'significant others' have considerable amounts of influence in our daily lives. The other one is the 'generalized attitude' which is the attitude towards the community (Mead, 1934). According to Mead, the 'generalized attitude' is often speculative based on the internalized attitude with the 'significant others'. However, the current discursive phenomena of 'identity' would probably question Mead's (1934) concept of 'internalization' of the attitude to others. However, Mead's (1934) claim about our differential approaches in terms of responding to the 'significant others' and to 'just others' can be very useful to examine the correlation between 'employer branding' and 'employee identity work'.

\section{The ReLATIONSHIP BETWEen EMPLOYER BRAND AND IDENTITY WORK}

Employee's reaction towards 'generalized others' can be described as company's corporate reputation, corporate brand or image. This is better explained by the concept of 'employer brand' distinguished from the approach of employee's attitudes towards the other three. The concept of 'employer brand' is about the impressions about the company to others specifically as an employer. However, it can be argued that the 'employer brand' is inspired to have a relation with company's corporate image in order to define a meaning with employee's identity work. It can serve as a significant concept to explore organizational identity to external environment. Aaker's (1997) brand personality research suggests that individuals have a desire to express their association with others externally that can be brands or groups. Therefore, it can be argued that the 'brand' can be served as a platform, for instance, individuals may try to associate brand when they try to present an attractive self- image to others. Brands can have significant symbolic associations, which individuals may utilize to define their 'who am I' question to others. Since individuals tend to identify themselves with their work organization, 'employer brand' concept can be a useful mechanism to correspond with others about the desire to be perceived as an employee of a certain organization. More interestingly, the research within corporate reputation has a more preferential approach towards the representation of the corporation to external audience. On the other hand, 'employer brand' concept is more meaningful since it takes into consideration of both internal and external audience while defining an organization. 


\section{EXTERNAL VERSUS INTERNAL EMPLOYER BRAND}

As discussed before, the concept of 'employer brand' works closely with both 'internal' and 'external' audiences. Therefore, 'employer brand' can be classified under three features- 'external employer brand', 'internal employer brand' and 'construed external employer brand' (Dutton, Dukerich and Hurquail, 1994). Historically, 'employer brand' is defined as "package of functional, economic and psychological benefits provided by the employment" (Ambler and Barrow, 1996:3). Ashcraft (2007) described that, the employer brand concept is a wider perspective in which construction of employee identity is largely incorporated within the quintessence of employer. According to Ashcraft (2007), the discourse of employer branding in which 'employee's identities are constructed have significance on prospective employees who impose a favorable/non-favorable attitude towards the employer. Internal employer branding is, therefore, described as the way employees in an organization articulate their attitude towards the internal organization, more specifically, it's about employee's experience in the organization. According to Uncles and Moroko (2008), existing employment condition serve as a harmonizing factor to reposition a firm complying with it's value, attitudes and stories of employee's experience in the workforce. The construed employer brand relates to the employee's beliefs about prospective employees perception of the organization. Employees are influenced in their image construction of the organization through 'feedback loop' from an external group which, in fact, is an acknowledgement of some interrelatedness. The reflection of this image that employees perceive from the external world is described as 'construed image'. Therefore, these three versions of 'employer branding' even after having distinguishing characteristics, could be argued to have an interrelation in an organizational setting and may influence the identity work of employees.

\section{EMPLOYER BRAND'S INFLUENCE ON IDENTITY IN NEGATIVE CORPORATE REPUTATION SETTING}

A few studies had reported 'employer brand' influence upon employee's identity work with empirical evidence especially when the firm had been tagged with negative corporate reputation. One study by Dutton and Dukerich (1991) about New York Port authority described the way a negative external image of the firm demolished organizational identification which encountered employees to go through stressful situations. Supported by Highhouse (et al. 2007), in an organizational setting with negative corporate reputation, employees encounter with shame and embarrassment. Therefore, the negative reputational settings may affect a firm's recruitment and retention activities which could be resolved by an overall improvement of the firm's corporate reputation (Fomburn and Van Riel, 2007). This argument, therefore, suggests that, employees prefer to construct a lucid, consistent and distinct identity which they can associate with their employer. Fomburn (et al. 2007), argued that employees prefer to associate themselves with positive external brand reputation setting in order to receive positive appreciation from others. This line of thought suggests that in a constructive external employer brand, employees feel motivated to comply with the values of the organization; the organizational identity becomes prevailing and encourages employees to construct a positive self-image. On the other hand, these arguments didn't explain the damage level of negative reputations and feedback from others towards employee 'identity work' when they do not correspond positively to the values of the organization. The literature studies of 'Dirty Work' can be taken into account to explain such issues. 


\section{THE LITERATURE OF 'DIRTY WORK'}

The literature of 'Dirty Work' illustrates the influence of stigmatized, tainted occupations upon identification and 'identity work' (Kreiner, Ashforth, and Sluss, 2006). It could be expected that the organizations with contaminated image or tainted jobs may impose challenge for individuals to construct positive sense of self and individuals may indulge themselves more with the construction of a negative self-image. However, the literature on 'dirty work' suggests that individuals belonging to contaminated employer image uphold their self-esteem and often express pride or honor associated with their work. According to Ashforth and Kreiner (1999), the techniques individuals use to correspond to the meaning of their identity work in such settings are 'refocusing, 'recalibrating' and 'reframing'. According to the authors, 'refocusing' is described as an individual's approach to take into considerations of non stigmatized features of the workplace instead of the associated negative reputations. Recalibrating is defined as the process that entails individuals to deny certain allegations or negative responsibilities. Reframing is defined as the transformation process of contaminated workplace characteristics into the 'pride work' (Ashforth and Kreiner, 1999). The authors argued that 'reframing' technique imposes a better 'identification' that may be sometimes greater than these in prestigious occupations. Other studies support the incorporation of reframing techniques in work-related identity conciliation in fuzzy, contaminated reputations of employers where 'identity work' could have been indulged with the negative image (Aschraft, 2007, Meisenbach, 2008). These studies serve as contradictions to the previously mentioned studies demonstrating individual's damaged 'identity work' in a negative external employer brand. Furthermore, these studies have higher significance in explaining the 'negative employer brand's influence towards 'identity work' and employee's contribution towards maintaining a positive self-image. An empirical study about 'employer's identity work' in both negative and positive external employer brand would better explain the existence of perceived difference in 'employees identity work'. It may also explain whether such differences may impact an organization's corporate identity and employee's enthusiasm.

\section{CONCLUSION AND FutuRE RESEARCH IMPLICATION}

The literature review tries to address the theoretical gap by providing a framework for understanding the relationship between the employer brand image and identity work. The concept of identity work is mostly derived from the disciplines of 'organization and sociology', complemented with the theories of employer branding in the field of marketing coupled with the distinct sociological literature on 'dirty work'. The main argument behind presenting this theoretical framework is to explain how employees construct their identity in relation to the organizational employer brand image. Therefore, a multidisciplinary approach is required to understand employee identity construction, through consideration of both positive (good employer brand image) and the negative (dirty work) side of an employment. The research questions that are needed to be empirically investigated is -

- $\quad$ "Is it possible for an employee to construct a positive self-identity despite the organization's having bad reputation or negative employer brand image? "

- "Alternatively, do all those employees working for highly reputed organizations with positive employer brand image construct a positive self-identity just because they work for prestigious organizations?" 
It's important to mention here that, understanding employee identity work in the context of organization can be very complex and subjective. The empirical study is therefore may be subjective and qualitative by nature which should focus employee identity work from both prestigious and non prestigious organizations. Future research in this field may introduce case studies of extreme companies (companies with highly positive employer brand image and companies with lower reputation) to explain the true nature of identity work in the context of employer brand image.

\section{REFERENCES}

Aaker, J. (1997). Dimensions of Brand Personality. Journal of Marketing Research, 34(3), 347-356

Alvesson, M., and Wilmott, H. (2002). Identity regulation as organizational control: Producing the appropriate individual. Journal of Management Studies, 39(5), 619-644.

Alvesson, M., K.L. Ashcraft, and R. Thomas. (2008). Identity Matters: Reflections on the Construction of Identity Scholarship in Organization Studies. Organization, 15(1), 5-28.

Ambler, T., and Barrow, S. (1996). The employer brand. Journal of Brand Management, Vol.4, 185-206.

Ashcraft, K. L. (2007). Appreciating the 'work' of discourse: Occupational identity and difference as organizing mechanisms in the case of commercial airline pilots. Discourse and Communication, $1(1), 9-36$.

Ashforth, B. E., and Kreiner, G. E. (1999). "How can you do it?" Dirty work and the challenge of constructing a positive identity. Academy of Management Review, 24(3), 413-434.

Ashforth, B. E., and Mael, F. (1989). Social identity theory and the organization. Academy of Management Review, 14(1), 20-39.

Brian E. Becker and Mark Huselid (1999), "Overview: Strategic Human Resources Management in Five Leading Firms", Human Resources Management Journal, Vol. 38. 4, pp. 287-301...

Cable, D. M., and Turban, D. B. (2003). The value of organizational reputation in the recruitment context: A brand-equity perspective. Journal of Applied Social Psychology, 33(11), 2244-2266.

Chowdhury AH, Chowdhury MS and Imran M. 2013. Branding strategies for service firms- a study on the selected Internet Service Providers (ISPs) in Bangladesh Asian Business Review, 2, 47-53.

Collins, C. J., and Stevens, C. K. (2002). The relationship between early recruitment-related activities and the application decisions of new labor-market entrants: brand equity approach to recruitment. Journal of Applied Psychology, 87(6), 1121-1133.

Crain, Marion G., Managing Identity: Buying into the Brand at Work (October 2, 2009). Washington U. School of Law Working Paper No. 09-10-01.

Deetz, S. (1995) 'Character, Corporate Responsibility and the Dialogic in the Postmodern Context: A Commentary on Mangham', Organization 2(2): 217-25

Dutton, J. E., and Dukerich, J. M. (1991). Keeping an eye on the mirror: Image and identity in organizational adaptation. Academy of Management Journal, 34(3), 517-554.

Dutton, J. E., Dukerich, J. M., and Harquail, C. V. (1994). Organizational images and member identification. Administrative Science Quarterly, 39(2), 239-263.

Fatema M, Azad MA and Masum AK. 2013. Impact of Brand Image and Brand Loyalty in Measuring Brand Equity of Islami Bank Bangladesh Ltd. Asian Business Review, 2, 42-46.

Fombrun, C. J., and Riel, Cees B. M. van. (2007). Essentials of corporate communication: Implementing practices for effective reputation management. London: Routledge.

Giddens. A. (1991) Modernity and Self-Identity: Self and Society in the Late Modern Age, Stanford, CA: Stanford University Press.

Goffman, E. (1990). The presentation of self in everyday life. London: Penguin Book 
Hatch, M. J., and Schultz, M. (2002). The dynamics of organizational identity. Human Relations, 55, 989-1018.

Highhouse, S., Thornbury, E. E., and Little, I. S. (2007). Social-identity functions of attraction to organizations. Organizational Behavior and Human Decision Processes, 103(1), 134-146.

Kärreman, D., and Alvesson, M. (2001). Making newsmakers. Conversational identities at work. Organization Studies, 22, 59-90

Kreiner, G. E., Ashforth, B. E., and Sluss, D. M. (2006). Identity dynamics in occupational dirty work: Integrating social identity and system justification perspectives. Organization Science, 17(5), 619-636.

Kuhn, T. (2006). A 'Demented work ethic' and a 'Lifestyle firm': Discourse, identity, and workplace time commitments. Organization Studies (01708406), 27(9), 1339-1358.

Lenaghan, Janet A. and Eisner, Alan B. 2005. An Exploration of the Competitive Advantage of Employer of Choice Programs on International Human Resource Management. Journal of International Business Research, Volume 4, Issue 2, pages 87-97

Martin, G. and Hetrick, S. (2006) Corporate reputations, branding and people management: a strategic approach to HR. Oxford: Butterworth-Heinemann.

Mead, G. H. (1934). Mind, self and society. Mind, Self and Society,

Meisenbach, R. J. (2008). Working with tensions: Materiality, discourse, and (dis)empowerment in occupational identity negotiation among higher education fund-raisers. Management Communication Quarterly, 22(2), 258-287.

Moroko, L. and Uncles, M. D. (2009). Employer branding. Wall Street Journal - Eastern Edition, 253(67), R7

Moroko, L., and Uncles, M. D. (2008). Characteristics of successful employer brands. Journal of Brand Management, 16(3), 160-175

Scott, C. R., Corman, S. R., and Cheney, G. (1998). Development of a structural model of identification in the organization. Communication Theory, 8(3), 298-336.

Shellenbarger, S. 1998a. Accounting Firms Battle to Be Known as Best Workplaces. Wall Street Journal, January 21, 1998, p. B1.

Sveningsson, S., and Alvesson, M. (2003). Managing managerial identities: Organizational fragmentation, discourse and identity struggle. Human Relations, 56(10), 1163-1193.

Tinne WS. 2013. Nation Branding: Beautiful Bangladesh Asian Business Review, 2, 31-36. 
Publish online and print version both 